\title{
The Dido Story in Accounts of Early Modern European Imperialism-
} An Anthology

\author{
A N D R EW NEW MA N* \\ E-mail: andrew.newman@stonybrook.edu
}

This anthology of excerpts from histories and travel accounts composed during the seventeenth, eighteenth, and nineteenth centuries features representations of indigenous oral traditions about the founding of European colonies in Sri Lanka, Melaka, Gujarat, Cambodia, Manila, Jakarta, Taiwan, New York, and the Cape of Good Hope. According to these accounts, the colonists first requested as much land as the hide of an ox could cover, and then cut that hide into strips and claimed all the land they could encircle. The "oxhide measure" is a widely-attested folkloric motif. The introduction, however, questions assumptions about the unreliability of oral traditions and looks to history instead of folklore for an explanation for the colonial parallels. It proposes that Portuguese, Spanish, and Dutch colonists performed the "hide trick" in emulation of the classical story of the Phoenician Queen Dido's founding of Carthage.

Keywords: Dido, Optimization, Oral Tradition, Oxhide Motif.

At a symposium at the State University of New York at Purchase in 1980, the late Delaware Indian (Lenape) elder Nora Thompson Dean (Touching Leaves Woman) explained that when the Dutch colonists first arrived in New York Harbor, they requested a small tract of land: only as much as a cow's hide could cover. They then cut the hide into strips, and claimed all the land it could encircle. According to James Rementer, who was her mentee and is now the director of the Lenape Language Project for the Delaware Tribe of Indians, a literature professor in the audience then stood up "and said in a smart-aleck way that was the same old Queen Dido story and what did she think about that." The questioner was referring to the classical story of the Phoenician Queen Dido, which was alluded to by Virgil and recounted by Livy (document 1). According to the story, Dido requested from the local king, Hiarbas, as much land as an oxhide could cover, and then cut the hide into strips, laid them out in the circle, and claimed the capacious site on which she built her citadel. To Dean, the professor's implication showed disrespect for her oral tradition. She responded: "Nothing." 
However, the late Herbert Kraft, a historian of the Delaware Indians who was also in the audience, pointed out that the tradition's resemblance to the Dido story did not invalidate it. The Dutch would have been familiar with classical history: perhaps they had reenacted Dido's ruse on the North American coast. ${ }^{1}$

The story Dean told at the symposium has been told by descendants of the indigenous inhabitants of the region of New York Harbor for at least two centuries. These oral performances have been recorded by ethnographers and others at intervals, along the stages of these Algonquian peoples' westward migration. ${ }^{2}$ I first came across the tradition while researching the 1737 Pennsylvania "Walking Purchase," a colonial land transaction that has been widely characterized as a fraud perpetrated by the Pennsylvania Proprietors, the sons of William Penn, on Delawares in eastern Pennsylvania. The implementation of the Walking Purchase hinged on the interpretation (in a contested deed), of the phrase "as far as a Man can goe in one day and a half." 3 The Proprietors hired three athletic men, set them off at an advantageous north-westerly trajectory, and pushed the pace of the "walk" to the extent that two collapsed from exhaustion (one died); the third covered about fifty-five miles. The Proprietors claimed a tract bounded by the course of the "walk" on the one side and by the Delaware River, with its northeasterly upstream sweep, on the other-approximately five hundred thousand acres. ${ }^{4}$

The Walking Purchase and the reported transaction with the bullock's hide are both instances of colonial optimization. Dido's ruse is actually a locus classicus for the mathematical concept of optimization: with a given perimeter, which shape encompasses the largest area? The solution is a circle. ${ }^{5}$ The Pennsylvania Proprietors' optimization of their agreement with the Delawares in 1737, and the agreement itself, were the focus of a mid-eighteenth-century political controversy in Pennsylvania, and are documented in a profuse, contentious archive. ${ }^{6}$ However, the earliest extant written record of an early seventeenth-century agreement to transfer to Dutch colonists on or near Manhattan of "only so much Land as the Hide of a Bullock would cover" is an 1801 letter from the Moravian missionary John Heckewelder to the historian Samuel Miller presenting the Indians' narrative account of the "Arrival of the Whites" (document 9).

Heckewelder insisted on the authenticity and accuracy of his written representation of the tradition, stating that he presented the account "verbatim as was related to [him] by Aged \& respected Delawares; Monseys [Munsees] \& Mahicanni [Mahicans]... nearly 40 years ago." He explained that the letter was "Coppied from Notes \& Manuscripts taken on the spot," in Western Pennsylvania or Ohio, where the descendants of the Indians who had inhabited the mid-Atlantic seaboard had migrated under pressure from encroaching settlers. ${ }^{7}$ One might otherwise suspect, as a famous nineteenth-century commentator apparently did, that Heckewelder himself "borrowed" the story "from antiquity," and perhaps thereby contaminated the oral tradition for future generations (document 11). For his part, though, Heckewelder seemed to consider the tradition not only authentic but accurate. In a footnote to a version he published in his History, Manners and Customs of the Indian Nations Who 
Once Inhabited Pennsylvania and the Neighboring States (1819), he suggested that the "Dutchmen were probably acquainted with what is related of Queen Dido in ancient history, and thus turned their classical knowledge to a good account." 8 Thus he anticipated Kraft's suggestion at the 1980 symposium.

There are two obvious problems with a accepting the Delawares' account of the oxhide transaction at face value. First, it corresponds to a folkloric formula, a trickster tale; neither the communicative event (the verbal agreement) nor the implementation (the cutting up of the hide) seem plausibly realistic. Second, as one might expect, with respect to the use of a bullock's hide, the tradition is utterly uncorroborated by the colonial records of the founding of New Netherland. Therefore, it makes sense to assume, as Americanist scholars have, that the story has a "metaphorical" rather than a literal accuracy. ${ }^{9}$ After all, its metaphorical truth is as indisputable as its literal truth is doubtful; the Walking Purchase is only one glaring example of the Native Americans' experience with treacherous agreements.

In what follows, however, I hope to at the least get readers to think critically about this seemingly common-sense (and implicitly ethnocentric) interpretation. For my own part, as I continued my research, I found the notion that the hide story was a sort of invented collective memory to be increasingly untenable. The other explanation, that Heckewelder embellished or fabricated the Delaware tradition, does not stand at all. That is because the Delaware tradition is part of a global archive - a set of accounts by colonized peoples attributing Dido's ruse to early modern European imperialists. For me, this archive, represented by the excerpts below, situates the Delawares' tradition in a new frame of reference, one that is synchronic and global rather than diachronic and local. In my view, any explanation for the Native American tradition should theoretically be able to account for its counterparts associated with Portuguese, Spanish, and Dutch landings in Sri Lanka, Malaysia, Gujarat, Cambodia, the Philippines, Burma, Java, Taiwan, and South Africa, and variously recorded in writing between early-sixteenth and late-nineteenth centuries. I find it very challenging to believe that colonized peoples, in these disparate sites of empire, all decided to adopt and adapt precisely the same motif to explain the foundation of the first European forts in their region, and impossible to believe that all these completely unconnected writers, from the author of the Chinese Account of the Eastern and Western Oceans in 1618 (document 9) to nineteenth-century French missionaries near the Cape of Good Hope (document 12), decided to make precisely the same intervention into the histories they were recording.

Notably, the instances of the oxhide story associated with European colonization are a subset of a larger folkloric motif: "Deceptive Land Purchase: Ox Hide Measure."10 Folklorists have collected many variants of this motif that do not involve European colonists, and others in which the resemblance to Dido's founding of Carthage is only vague. In a note on "Hide-Measured Lands" in The Classical Review, for example, the famous Victorian social anthropologist James Frazer lists five "parallels" to the Dido story. Of these, three - from Siberia, Burma, and Bali- do not involve European colonists. In the one from Siberia, the instrument of measure, employed by the Tartar 
hero Jermak, is a hide converted into a thong and tied to a pole; the circle is formed by the radius. In the one from Bali, it is the odor of a horse carcass, which "the people of Tenganan" optimized by cutting it into pieces and walking off in different directions. But the versions from Cambodia (document 5) and Java (document 7) involve Dutch colonists using Dido's ruse to found forts. ${ }^{11}$ When these instances are coupled with the parallels from New Amsterdam (documents 9-11), Formosa (document 8), and South Africa (document 12), the folkloric question becomes an historical one: Why and how does this story become particularly associated with the foundation of Dutch imperial outposts? This question set the agenda for my research, which expanded to consider the Portuguese and Spanish examples as well.

Other scholars who have noted a partial subset of colonial Dido stories have been puzzled by their pattern of distribution. Discussing "The Dido Story in Asia" in 1907, the sinologist Berthold Laufer characterized it as "one of the few examples of a Western tale spreading to the extreme East, while as a rule the stream of folk-lore flowed from east to west in the old world." He speculated that its "occurrence in southern and eastern Asia is due to the oral stories of European sailors and merchants, who had probably imbibed it during their school-days, while its propagation in Siberia seems to have emanated from the mouths of vagrant Russian adventurers." ${ }^{2}$ For Laufer, the motif is "nothing more than a simple tale, which has spread over almost the entire continent of Asia, and it is most curious to note that in nearly all cases the Asiatic peoples with whom the story is found make the tricksters some European nation who were then invading their country."13 Thus he acknowledged some intersection between folklore and colonial history, but he dismissed what the historian James Davidson would later claim, that "the wily Dutchman with an old trick in mind" practiced Dido's ruse in Formosa (Taiwan). ${ }^{14}$ Laufer pointed out that there is absolutely no corroboration for such an account in "the Dutch sources regarding the history of Formosa." This dismissal expresses the language ideology of archival positivism: if it's not in the written records, it did not happen.

More recently, the historian Anthony Reid suggested that "the Batavia experience" - the establishment of a Dutch stronghold at Jakarta - "seems the likeliest origin for a trickster story that spread quickly around Southeast Asia." Not only was the Dutch use of the hide trick recounted by "several Javanese histories," but the Portuguese use of the ruse at Melaka was told "by a number of Malay texts." Reid's speculation is that the story may have been introduced by "the Portuguese themselves," or "much earlier through the long-established Middle Eastern connection." At the point of introduction, the colonized people incorporated it into their history as a magical explanation for "how a handful of people coming from the other side of the world, ostensibly to trade, could have ended by making themselves impregnable and strangely powerful." From Batavia it spread to other sites where Europeans established colonial beachheads. But while the transmission of the "trickster" story between Java (document 7) and Malaysia (document 3) was plausible, Reid finds it "surprising to find exactly the same story told in the 
Burmese chronicle of Syriam, where the trick is attributed to the Portuguese adventurer Felipe de Brito." 15 According to the undated History of Syriam, de Brito gave the local King "many presents, muskets, lead and powder asking that he might be allowed to found in our town of Syriam a village such as might be included in a hide. When his request had been granted he drew out the hide like a wire and on the North, South, East and West, he measured out land." ${ }^{16}$ Reid, who was apparently unaware that "exactly the same story" has appeared at such far flung locales as South Africa and North America, had "no explanation to offer as to how this legend traveled so far" as Burma.

I do have an explanation, one that accounts, however, problematically, for the complete set of Dido stories attached to European colonization. But before I get to it, I want to address the assumptions underlying Laufer's and Reid's explanations, and folkloric treatments of the Dido motif. In the most comprehensive folklorist discussion of the Native American instances of the Dido story in a global context, Jason Baird Jackson points to "the very strong likelihood that Europeans were both the source of, and the motivation for, the incorporation of the oxhide narrative into the living oral history traditions" of the Yuchis, Wyandots, and Delawares. ${ }^{17}$ In other words, colonists introduced the story by word-of-mouth, perhaps recounting to Delaware Indians the story of Dido's foundation of Carthage (such a conversation itself would be a noteworthy event). That initial audience, associating the hide trick with their own experience with Europeans, perhaps especially with the Walking Purchase, then incorporated the Dido story into their historical traditions as an event that happened to them, changing Dido and the Phoenicians for "the Whites" and themselves, respectively. According to this model, as the Delawares travelled westward, they transmitted the story to other native peoples whom they encountered in their "diaspora." 18

Unlike Reid in his study of Southeast Asia, Jackson can establish that there were occasions for cultural transmission between the Native American peoples among whose traditions the Dido motif is found. However, word-of-mouth among colonized peoples cannot account for the transmission of the motif across oceans. To account for the full distribution of the colonial Dido motif, we would need to suppose that the same series of discursive events unfolded independently from multiple points of introduction: 1) The colonists made the curious, altogether undocumented decision to recite, to the very people they were invading, the story of Dido's foundation of Carthage. 2) Hearing the story, the colonized peoples decided to incorporate it into their historical "narrative accounts," sometimes within a generation or two of the colonial landings. ${ }^{19}$ 3) From this point of introduction, the story spread to other colonized peoples, who also incorporated it as an event that happened to them. Somehow, the outcome was nearly a dozen or so nearly identical accounts of Europeans employing Dido's ruse to found colonial forts.

In fact, the North American distribution discussed by Jackson contradicts the implicit assumptions concerning the Asian distribution, because the Wyandots and 
the Yuchis did not recount the story of the oxhide purchase as an event experienced by their own ancestors. On the contrary, the Wyandot (or Huron) version, recorded by Marius Barbeau in 1912, explicitly identifies "the Delawares" as the unfortunate grantors, who consented to the treacherous agreement and then "sent messengers to the Wyandots" to tell them what had happened. ${ }^{20} \mathrm{~A}$ Yuchi version, also from the early twentieth century, describes the transaction as occurring between "the red people" and the "pale faced White people" on an island "somewhere under the rising sun." 21 Thus other Native American peoples incorporated the hide story into their oral traditions not as something that occurred to them, but rather as something that occurred to other Indian nations, and thereby became part of the collective Native American story of colonization. For the folkloric, word-of-mouth explanation to apply to the Asian (and South African) instances, we would need to suppose not only that the tradition was transmitted across seemingly insurmountable distances, but also that their histories, including written records, were more permeable than those of the Native Americans.

My published explanation for the distribution of the Dido motif agrees with Nora Thompson Dean, Herbert Kraft, John Heckewelder, and James Davidson. My thesis is that Portuguese, Spanish and Dutch imperialists intentionally emulated Dido's ruse. This thesis has the advantage of clear "information flows." ${ }^{\text {"2 } 2}$ While the hide cut into strips was an exogenous element, certainly, in most if not all of the cultural traditions of the grantors in the reported transactions, it was part of the shared classical canon of the imperial grantees. And while the peoples who have told the story and the writers who recorded it are mostly unconnected, the colonists were linked through the Habsburg Empire. Notably, the ruse is nowhere attributed to British or French colonists. It is most associated with the Portuguese, and with the Dutch, who borrowed the Portuguese imperial modus operandi. ${ }^{23}$ As Livy's version (document 1) illustrates, there was no better classical precedent for Portuguese and Dutch imperialists than Dido's founding of Carthage. She acquired land, built a fort, and established a thriving maritime trading post that developed into a "mercantile superpower." ${ }^{24}$ Thus while the hide story may have resonated with the subsequent experiences of colonized peoples, epitomizing the Europeans' "Punic faith," it was directly relevant to the unfolding narrative in which the colonists saw themselves as protagonists. ${ }^{25}$

This explanation accounts for the full distribution pattern, from New York to Manila to the Cape of Good Hope, as well as for the absence of attributions of the hide trick to non-Habsburg maritime powers. It substitutes a repeated, improbable, and otherwise unattested "ceremony of possession" for multiple, parallel, series of improbable intercultural communications and discursive mutations. ${ }^{26}$ Arguably, its greatest point of vulnerability is also its greatest value, because it tells us something about early modern imperialism that the colonists' own extant records (so far as I know) do not. Thus, in addition to suggesting that early modern maritime imperialists were even more invested in and imitative of classical precedents than has been recognized, and testifying to the commonality in the experiences of colonization, 
it also has methodological implications for the consideration of oral traditions and non-Western histories as historical evidence.

Some scholars understandably find my thesis implausible. At least one reviewer found it "frustrating" that I didn't do more to prove my case. ${ }^{27}$ To my mind, that reaction misses the point. As far as I can ascertain, my thesis is neither provable nor falsifiable. Indeed, I am not sure what sort of evidence would constitute definitive proof-multiple, corroborating written records of perpetrating the hide trick, produced by the perpetrators themselves? Instead, this argument expresses an epistemological principle, which is that the dependence on conclusive evidence can produce a distorted, incomplete understanding of the past, and that speculative interpretations based on uncertain evidence can actually be more rigorous. Nevertheless, I must acknowledge my own limited perspective, as an early Americanist literary scholar, in approaching this global archive. By bringing this set of documents to the attention of the readers of Itinerario, I hope to elicit other insights, new or overlooked evidence, and perhaps alternative explanations from varied regional and disciplinary perspectives. I hope, at the least, that readers will agree with my initial premise, which is that the attribution of the trick with the bullock's hide to European colonists at so many disparate sites constitutes a phenomenon requiring explanation.

\section{Documents}

\section{Carthage}

According to various classical sources, the Phoenician Queen Dido (also known as Elissa) used the hide ruse to acquire the site for the citadel at Carthage from the Tunisian King Hiarbas. This story is alluded to in Virgil's Aeneid:

mercatique solum, facti de nominee Byrsam,

taurino quantum possent circumdare tergo (I.367-68)

In John Dryden's translation:

At last they landed, where from far your

Eyes May view the Turrets of new Carthage rise:

There bought a space of Ground, which Byrsa call'd

From the Bulls hide, they first inclos'd, and wall'd. ${ }^{28}$

(Byrsa means "hide" in Greek, and it resembles the Phoenician word for citadel.)

Dido's foundation of Carthage (see figure 1) was apparently recounted in the lost "second decade" of the History of Rome of Livy (Titus Livius), whom early modern readers looked to for "the justification of republicanism and imperialism." ${ }^{29}$ It is reconstructed in Johann Freinsheim's widely-translated "Supplement" (1649), excerpted below from a 1659 edition containing Philemon Holland's 1600 translation of the extant books. 


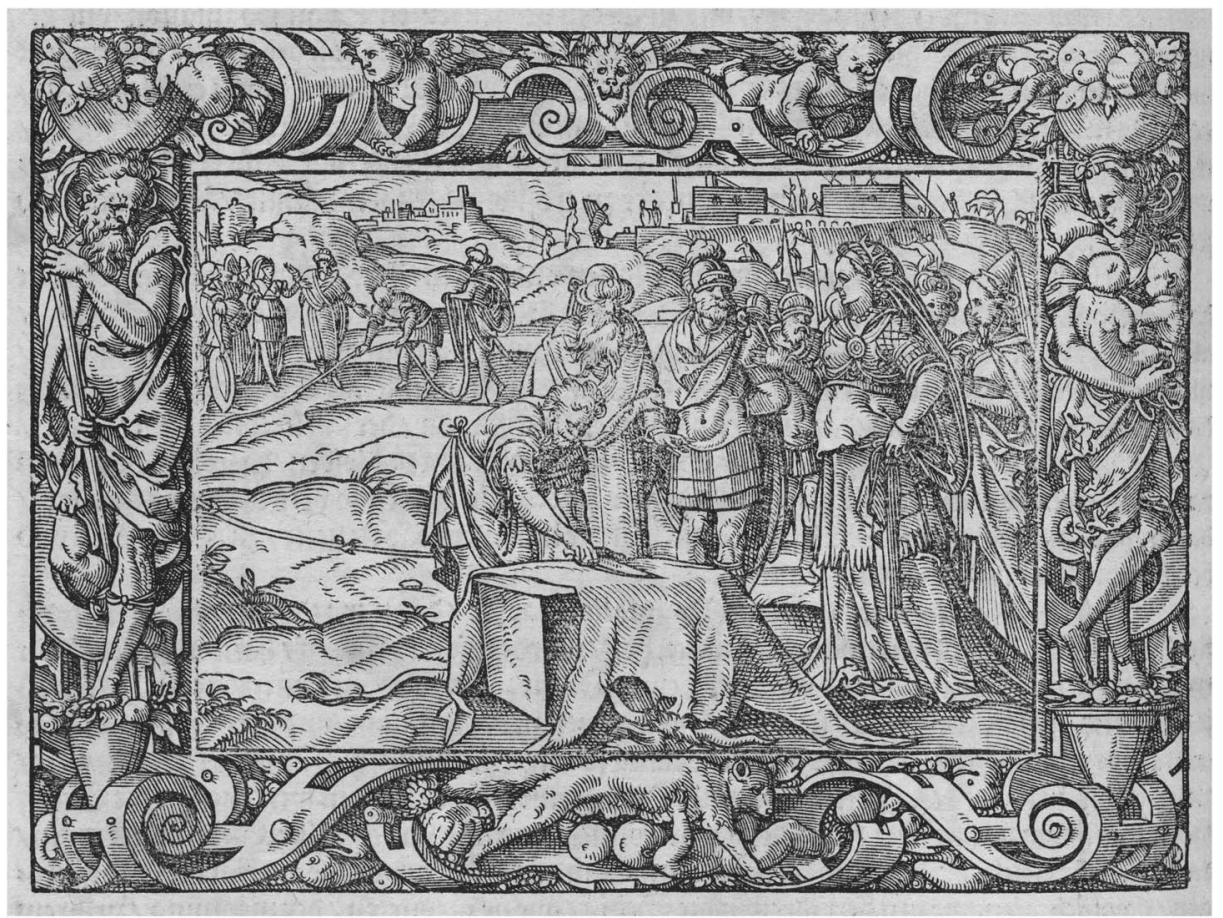

Figure 1. Dido Cutting the Oxhide, woodcut by Tobias Stimmer, in Titus Livius and Lucius Florus, Von Ankunfft unnd Ursprung des Romischen Reichs... Straszburg, 1575, fol. 220. Courtesy of Houghton Library, Harvard University. [OLC. L765.En575]

\section{J. Freinshemius, “A Supplement of the Second Decad of Livie's Roman History”30}

That Carthage was built by the Tyrians of Phønicia (besides the constant agreement of old Histories) the perpetual friendship of those Cities where they flourished, as also the manifest likeness both of their Language and Manners doth clearly testifie. 'Tis reported that Elisa (who was likewise called Dido) the daughter of Agenor the son of Belus, flying out of her Country (by reason of the hatred she bore to her brother Pigmaleon for the unjust slaughter of her husband Sichaus) entred that Creek of Africa, and possessed that Peninsula where Carthage was afterward built; her small beginnings promising little hopes of so great power and wealth as afterwards was obtained: For 'tis believed Dido purchased no more ground then might be compassed with the hide of a Bull or Ox, which being cut out into very slender thongs contained a larger space, than the sellers did imagine, and it was sufficient whereon to Erect a Castle, which from thence is thought to be called Byrsa. Afterward seeing (many placing their habitation near to them for Traffick sake) they began to look like a City, and that the Africans were willing to entertain among them men so rich and very gentle and quiet, they hearkened to the counsel sent from Utica (which was also a Colonie of the Tyrians) which advised them, After their example to build a City. So it was agreed, That the Africans should afford them ground, and that the Phonicians in recompense thereof should pay a yearly Tribute. 


\section{Sri Lanka}

The Portuguese in Sri Lanka arrived from India around 1505, and constructed their first fort near Colombo around 1518. ${ }^{31}$ A Sinhalese "war poem" from the late seventeenth-century, the Maha Katana, recounts the transaction between the Sinhalese king and the Portuguese.

2. Kirimatiyawe, Maha Hatana, Stanzas $2-13^{32}$

Stanza 2. When king Bhuvanekaba was reigning justly and gaining fame, as if King Sakra had descended from heaven in the famous isle of Lanka.

Stanza 3. The Portuguese, having had a pleasant stay in India, loaded valuables on their ships and came to blessed Lanka and saw its riches.

Stanza 4. With their ships caught in a storm and losing their sails, the Portuguese made landfall at the port of Colombo by sheer physical strength.

Stanza 5. Having entered Lanka, they gathered their presents, placing them on their heads and, (making everyone) happy, went to see king Bhuvanekaba.

Stanza 6. Seeing the resplendent ruler, they kept aside the gifts that they had brought and, paying their respects by lowering their heads without reserve, they waited on the side after falling down at the [king's] feet.

Stanza 7. The king, who shone like the full moon and was as beautiful as a burnished golden statue, asked, "What are you called, you who fall before my clean feet?"

Stanza 8. "We are called Portuguese from the city of Goa in India, which is full of prosperous people and where there are prosperous merchants.

Stanza 9. "We have brought many attractive goods from India and all imaginable kinds of valuable things. Please give us a plot of land extensive enough to lay a cowhide so that we might stay and trade with all comers."

Stanza 10. The good ruler granted the extent of a cowhide in the city of Colombo, to which many ships come, so that they could trade with all comers without trouble.

Stanza 11. When the just, compassionate ruler granted land equal to a cowhide, the Portuguese, full of wisdom, tore the cowhide into hair-thin strips.

Stanza 12. Having promised king Bhuvanekaba to trade from the land and having promised to pay dues to him, [the Portuguese] seized the land, built a fort and thought of taking over the country.

Stanza 13. Having obtained permission from the king of Lanka, they stretched the torn cowhide so that it enclosed much land with it and, quickly using wood and stones, they built a strong fort, which was like a royal residence.

\section{Melaka, Malaysia}

About two centuries after the Portuguese conquest of Melaka (1511), an oral tradition relating the event was written down as part of the Hikayat Hang Tuah, a set of oral traditions recounting the adventures of Hang Tuah, a hero of fourteenth- and fifteenth-century Melaka. ${ }^{33}$

\section{The Hikayat Hang Tuah (ca 1700 AD) ${ }^{34}$}

By the Will of Allah, without warning a Portuguese vessel arrived from Manila, carrying goods to be traded. The captain was a well-mannered man; he presented himself before the Bendahara Paduka Raja, carrying with him many gifts. He presented a thousand tahil of gold each to the Temenggung, the Laksamana and 
Puteri Gunung Ledang. The captain requested the Bendahara for a place for them to lodge before the main gates of the negeri. So the Bendahara, the Temenggung and the Laksamana conferred with all the ministers and officials, and they decided that they could not allow them to trade from their vessel. So they traded, and after they had concluded their transactions for the season they sailed back to Portugal.

A year after that a huge vessel arrived from Portugal. The captain was a different Portuguese man, bringing with him a heavy load of gold, silver and weapons; there were no goods to be traded, for the vessel carried only gunpowder, cannon balls, and stone pillars for the building they proposed to erect.

The captain lost no time in disembarking and presented himself before Puteri Gunung Ledang, carrying with him scores of bahara of gold and silver, asking to buy a piece of land just the size of the hide of a cow; he said as a place from which to trade.

Puteri Gunung Ledang consented, "Very well, what price are you willing to pay for the piece of land as big as a cow-hide? Let me give it to you for the price of the amount of rials heaped on the hide, as high as it is wide."

The captain said, "Very well, let me convey Your Majesty's wishes to my superiors."

The captain then ordered his crewmen to fetch the rials from his vessel, and he brought them to the palace and presented in great heaps to the Raja. The Bendahara and the Temenggung and the Laksamana and all the officials and ministers conferred.

Someone said, "Let's convey our opinion not to allow them to the Raja, for the Portuguese are evil."

Someone else argued, "Let it be, what harm can a piece of land the width of an ox-hide cause?"

So the heaps of rials were accepted and stowed away in the go-down.

Soon after that the captain sought leave of the Raja and the Bendahara to return to his vessel. He sliced up the hide, which was turned into a rope and he ordered his sailors to carry the stones and all the equipment for the go-down, and heaped them down before the main gates of the fortress. The captain landed with the rope of hide, pulling it in the form [sic] a square, as big as it could stretch. It was there that he erected a great, tall building, extremely formidable, reserving holes for seven levels of cannon.

Meanwhile the Bendahara, the Temenggung and the Laksamana requested that the Raja order her men to stop the construction of the building, for the amount of land taken was too large. The agreement between Her Majesty and the captain was that they were merely given a piece of land the width of a hide. However, even though the men of the Bendahara and the Temenggung ordered them to stop, they paid no heed, and continued to build relentlessly in their determination.

The captain replied, "I bought it with countless bahara of silver; the Raja's promise to me is a piece of land as wide as a hide; this hide I had twined into a rope."

It was in such a manner that the go-down was built, complete in all its parts. And the inhabitants of Melaka were ignored by the Portuguese, and they were left to build as they wished. When it was ready, they carried up all the equipment and gunpowder into the go-down, saying that the barrels were containers for rice to be stored there. This was the way that the inhabitants of Melaka were made forgetful of their own welfare, entranced by beautiful objects and merchandise that came from the sea.

\section{Diu, Gujarat (India)}

In A New Account of the East Indies (1744), Alexander Hamilton refers to "a Tradition, that the Portugueze circumvented the King of Guzarat, as Dido did the Afrikanus, when they gave her leave to build Carthage, by desiring no more Ground to build their Cities 
than could be circumscribed in an ox's Hide, which having obtained, they cut it into a fine Thong of a great Length, and overreacht their Donors in the Measure of the Ground." ${ }^{35}$ This tradition, regarding the Portuguese acquisition of the Port of Diu from the Sultan Bahadur in 1534, was also recorded by non-European historians in the early-seventeenth century. The following excerpt is from Mirati Sikandari, or The Mirror of Sikandar, by Sikandar ibn Manijhu. ${ }^{36}$ The historian Hajii al-Dabir, commenting on this account in his contemporary Arabic History of Gujarat, wrote that he had consulted with "the old persons who were with Baha-dur at Div," and none had mentioned "the demand of a place in proportion to the ox-hide"; he claimed that the "story of the ox-hide stated in connection with the Firangis [Portuguese] is in respect of the ruler of Hormuz." ${ }^{37}$

4. Sikandar, Mir-Ati Sikandari (ca. 1611) ${ }^{38}$

When by the turn of the wheel of fortune, Sultán Bahádur was defeated, as has been described above, and he came to Dív, the Firangis offered to serve him and showed him sympathy, saying that the ports of the seas were in their hands and that to whichever port the Sultán wished to go they were ready to serve him in every way. On his part the Sultán also began to treat them with mildness. One day they represented that the goods of the traders of their race who came to Dív had to remain dispersed and in great insecurity, so that if the Sultán gave them land equal only to a cow's hide in extent, that they would enclose it within four walls, for the safety of their goods. The Sultán granted their request. After this, when the Sultán left Dív and went against the enemy, the Firangis got a cow's hide and cutting it up into thin ribands enclosed land according to its measure and built a strong fort and mounted it with pieces of ordnance and occupied it. When this news reached the Sultán he became very anxious and began to think of dislodging these infidels. But he wanted to gain his object by artifice and stratagem, or by the easiest of means. He went from Ahmedábád to Cambay and from that place set out for Dív. The Firangis thought that the arrival of the Sultán meant some treachery, and though the Sultán adopted the most amiable demeanor towards them, the Firangis took it to signify the reverse.

\section{Cambodia}

Louis de Carné represents a tradition that the Portuguese, who arrived in Cambodia in the mid-sixteenth century, implemented "the ruse of Dido's companions"; according to Adolf Bastian, however, his informants attributed the action to the Dutch. Possibly, in light of the generalisation about Europeans recorded by de Carné, either one author or the other made a mistaken inference about the nationality of the colonists referred to by the tradition they recorded. ${ }^{39}$

\section{Louis de Carne, Voyage en Indo-Chine et dans l'empire chinoi $(1872)^{40}$}

Towards the middle of the $16^{\text {th }}$ century, the Portuguese arrived to settle in this country, where one can still recognize in their descendants certain traits of their race; they left behind records that would have been, at least for the history of that époque, a source of precious information; but the Siamese destroyed them. These Portuguese upon their arrival requested of the king a tract of land [coin de terre]. He permitted them to determine for themselves the amount of land they would need. They humbly declared that they wanted an area the size of a buffalo hide; then, renewing the ruse [l'escamotage] 
of Dido's companions, they appropriated a large tract. Since that day, the Cambodians readily say of a Christian that he comes from the village of the stretched-out hide.

\section{Adolf Bastian, A Journey in Cambodia and Cochin-China $(1864)^{41}$}

There used to be an island at the confluence near Panompeng, called Ko Phra Sassana (island of the holy religion). One night about 60 years ago this island suddenly disappeared, since when the people had believed their religion was in decline. The French were negotiating to have a warehouse built on the island, which dominated the confluence, but the Cambodian ministers were afraid that it might be turned into a fortification, as had happened during the time of the Dutch. Hundreds of years previously, so I was told, the latter had come with their great ships and founded a trading post in Pinhalue (Panom Kjang Sabek), where they had dug the canal which linked up with Kampong Luang and which was still called Khlong (Preht) Farang today. When they had first arrived, they had requested a very small piece of land, just big enough to be covered with a buffalo hide, but after gaining royal approval, they had cut the hide into ribbons and had encircled a wide area, on which they had planned to build a fortification as in Java.

\section{Manila, Phillippines}

The tradition that the Spaniards used the ruse in their founding of Manila (1574) was reported by the Chinese official Zhang Xie in 1618. It was subsequently recorded in the Annals of the Ming Dynasty. Berthold Laufer, writing for the Smithsonian Institution in 1907, compared the account in the Ming Annals with Antonio de Morga's 1609 account of the conquest of Manila, and concluded that the former "is not quite without foundation in some details": according to De Morga, the conquistador Miguel López de Legazpi "took as much land as he needed for the city" ("tomó lo que bastó del terreno para la ciudad"). ${ }^{42}$

6. Zhang Xie, Dong-xi-yang kao (Tung-hsi-yang k'ao) [Account of the Eastern and Western Oceans], $1618^{43}$

There were some Franks [Fo-lang-ji] who called their own country Gan-xi-la [Castile] and who came from the West. They wished to trade at Luzon. Their chief secretly said: "This place can be taken and ruled." He thus sent gold and offered it as a wish for long life to the Luzon king, and sought land of the size of a buffalo hide, in order to build houses. The king was trusting and allowed this. The Franks then took the buffalo hide and cut it into strips, joining them together, which they then extended as a perimeter around a piece of land and they asked for the land to be given as promised. The king was in a dilemma, but did not want to lose the trust of the distant foreigners. He thus eventually gave them the land, with a monthly tax levied in accordance with the laws of their tribe. The Franks obtained the land, built walls and barracks and arrayed their cannons and weapons in abundance. After a time, they surrounded Luzon, killed the king, drove [his people] into the hills and Luzon gradually came to be controlled by the Franks.

\section{Jakarta, Java}

The British East Indian Company official Thomas Stamford Raffles reports the following account of the Dutch possession of Jakarta, which they renamed Batavia, in 1619. 


\section{Thomas Stamford Raffles, Esq. The History of Java $(1817)^{44}$}

The Javan historians considering the Dutch in light of other foreign nations, who were in the habit of trading to the sea coasts, do not furnish us with any information concerning the disputes which took place at Bantam, or in the first instance at Jákatra. Even in their accounts of the occasion of the first hostilities which took place with the Sultan of Matarem, they convey rather a notion of what is the general impression regarding the establishment of the Dutch, than any particulars calculated to throw light on the history of that period. "The Dutch," say they, "before they arrived at Jákatra, had formed an alliance with the Sultan of Bantam. They subsequently treated with the English, and with Pangéran Jokárta; but in a short time they found the way to play off a foul stratagem on the latter. In the first place, when they wished to ascertain the strength and resources of Jakátra, they landed like máta-mátas (peons or messengers), the captain of the ship disguising himself with a turban, and accompanying several Khójas (a term by which the natives of the Coromandel coast are distinguished). When he had made his observations, he entered upon trade, offering however much better terms than were just, and making more presents than were necessary. A friendship thus took place between him and the prince: when this friendship was established, the captain informed the prince that his ship wanted repair; and the prince, at his request, allowed the vessel to be brought up the river. There the captain knocked out the planks of the bottom and sunk the vessel, to obtain a pretence for farther delay, and then requested a very small piece of ground, on which he might build a shed, to store the sails and other property, which endeavours should be made to raise the vessel. This request was also complied with. The captain then made a wall of mud, so [154] that nobody could know what he was doing, and in the mean time courted the friendship of the prince. He afterwards waited on the prince, and requested as much more land as could be covered by a buffalo's hide, on which he might build a small póndok. This being complied with, he cut the hide into strips, and claimed all the land he could enclose with them. To this also the prince, after some hesitation, consented. The captain then went on with his buildings, engaging that he would pay all expenses. When the fort was finished, the mud wall was removed; batteries were unexpectedly displayed, and under their protection the Dutch refused to pay a doit. War then commenced, in which the Dutch were reduced to such an extremity, as to be obliged to use stones in lieu of balls, which were expended. Even this resource failed; and, as a last expedient, bags of the filthiest ordure were fired upon the Javans, when the fort has ever since borne the name of Kóta tái."

Such is the aversion of the Javans for the Khójas, as well on account of their general character as of their conduct on this occasion, that it is a proverb among them, "If you meet a snake and a Khoja in the same road, kill the Khoja first, and afterwards the snake."

\section{Taiwan}

The Dutch erected the stockade that eventually became Castle Zeelandia overlooking the Anping Harbor (Tainan) in 1623. In 1694, the Chinese Gazetteer of the Prefecture of Taiwan recorded that the Dutch used the ruse with the oxhide to cozen Japanese colonists who had arrived before them. The visiting Jesuit missionary Joseph Anna-Marie de Moyria de Mailla cited this account in a 1715 letter. $^{45}$ 
8. Letter of Father de Mailla, $1715^{46}$

Towards the end of the year 1620, which was the first year of the reign of Emperor Tien-ki, a Japanese squadron arrived at Formosa. The commanding officer found the country, as uncultivated as it was, to be suitable for founding a colony: he resolved to undertake to do so, and for that purpose he left behind a party, with orders to make the necessary reconnaissance for the execution of his plan. Around the same time a Dutch vessel that had been on the return trip to Japan was blown to Formosa by a storm; the Dutch found the Japanese were hardly in a state to pose a threat. According to the Chinese historian, the country seemed attractive to the Dutch, and advantageous for their commerce. They offered the pretext of a need for refreshments, and the supplies necessary to repair their ship, which had been damaged by the storm. Some of them went inland, and after examining the country, returned to the ship. The Dutch didn't touch their ship at all during the absence of their companions; they didn't consider repairing it until they had returned. They solicited the Japanese, whom they didn't want to upset out of fear of losing their commerce, to allow them to build a house on the coast of the isle that is in one of the entries to the port, from which they could subsequently derive some benefit, with regard to their commerce with Japan. The Japanese initially rejected the proposition, but the Dutch insisted in such a manner, assuring them that they wouldn't occupy any more land than could be enclosed by an oxhide, that at last the Japanese consented. The Dutch then took an oxhide that they cut into small, fine threads, which they laid down end to end, and served them to measure the land they wanted. The Japanese were initially somewhat angered at this trickery: but upon consideration it came to seem funny to them, and they relented, allowing the Dutch to do what they would with the land. This was the tract upon which they built the Fort which I wrote about above, and of which I sent you the Plan: one can still see today the words above the gate: Castel Zelanda 1634.

\section{New York}

The Moravian missionary John Heckewelder spent decades living among Delawares and "kindred tribes," in the mid to late eighteenth-century. ${ }^{47}$ His works informed James Fenimore Cooper's The Last of the Mohicans (1826), and is a principal source of ethnographic data for modern scholars. ${ }^{48}$ Document 9 is an excerpt from the first written record of the Algonquian oxhide story, Heckewelder's 1801 letter to the historian Samuel Miller, conveying the traditional "Account of the first arrival of Europeans at York Island." 49 Document 10 is an excerpt from the second of two versions of the hide story presented in Heckewelder's An Account of the History, Manners and Customs of the Indian Nations that Once Inhabited Pennsylvania and the Neighboring States (1819). It appears in the third chapter, on "Indian Relations of the Conduct of the Europeans Towards Them," which represents "the complaints which the Indians make of European ingratitude and injustice" in the form of quoted monologue, attributed to a collective, first-person plural spokesperson. "Often I have listed to these descriptions of their hard sufferings," Heckewelder commented, "until I felt ashamed of being a white man." This version shows the correspondence of the Native American tradition with its global counterparts, because it specifies that the colonists erected a fort on the land the hide encompassed. Possibly, Washington 
Irving's discovery of Heckewelder's manuscripts in the New-York Historical Society inspired him to revise his satirical Knickerbocker's History of New York (1809); his parody of the Dido motif (document 11) first appears in the 1848 edition (see figure 2).

\section{John Heckewelder, Letter to Samuel Miller, $1801^{50}$}

Familiarity daily increasing between them $\&$ the Whites, the latter now proposed to stay with them, asking them for only so much Land as the Hide of a Bullock would cover (or encompass) which Hide was brought forward \& spread on the Ground before them That they readily granted this request; whereupon the Whites took a Knife \& beginning at one place on this Hide, cut it up, to a Rope not thicker than the finger of a little Child; so that, by the time this Hide was cut up there was a great heap - That this Rope was drawn out to a great distance \& then brought round again so that both ends might meet - That they carefully avoided its breaking, \& that upon the whole it encompassed a large piece of Ground - That they (the Inds) were surprised at the superior wit of the Whites, but did not wish to contend with them about a little Land, as they had enough - That they \& the Whites lived for a long time contentedly together, altho' those asked from time to time more Land of them; \& proceeding higher and higher up the Mahicanituck (Hudson River) they believed they would soon want all their Country, \& which at this time was already the case -

\section{An Account of the History, Manners and Customs of the Indian Nations that Once} Inhabited Pennsylvania and the Neighboring States $(1819)^{51}$

"By and by the Dutchemaan* arrived at Manahachtánienk,"** (here they relate with all its details what has been said in the preceding chapter.) "The great man wanted only a little, little land, on which to raise greens for his soup, just as much as a bullock's hide would cover. Here we first might have observed their deceitful spirit. The bullock's hide was cut up into little strips, and did not cover, indeed, but encircled a very large piece of land, which we foolishly granted to them. They were to raise greens on it, instead of which they planted great guns; afterwards they built strong houses, made themselves master of the Island, then went up the river to our enemies, the Mengwe [Iroquois], made a league with them, persuaded us by their wicked arts to lay down our arms, and at last drove us entirely out of the country."

*The Hollanders. [Heckewelder's note]

**Manhattan, or New York Island. [Heckewelder's note]

\section{Washington Irving, A History of New York, from the Beginning of the World to the End of the Dutch Dynasty ${ }^{52}$}

As the little squadron from Communipaw drew near to the shores of Manna-hata, a sachem, at the head of a band of warriors, appeared to oppose their landing. Some of the most zealous of the pilgrims were for chastising this insolence with powder and ball, according to the approved mode of discoverers; but the sage Oloffe gave them the significant sign of St. Nicholas, laying his finger beside his nose and winking hard with one eye; whereupon his followers perceived that there was something sagacious in the wind. He now addressed the Indians in the blandest terms; and made such tempting display of beads, hawks'-bells, and red blankets, that he was soon permitted to land, and a great land speculation ensued. And here let me give the true story of the original purchase of the site of this renowned city, about which so much has been said and written. Some affirm that the first cost was but sixty guilders. The learned Dominie Heckwelder [sic] records a tradition* that the Dutch discoverers bargained for only so much land as the hide of a bullock would cover; but that they cut the hide 


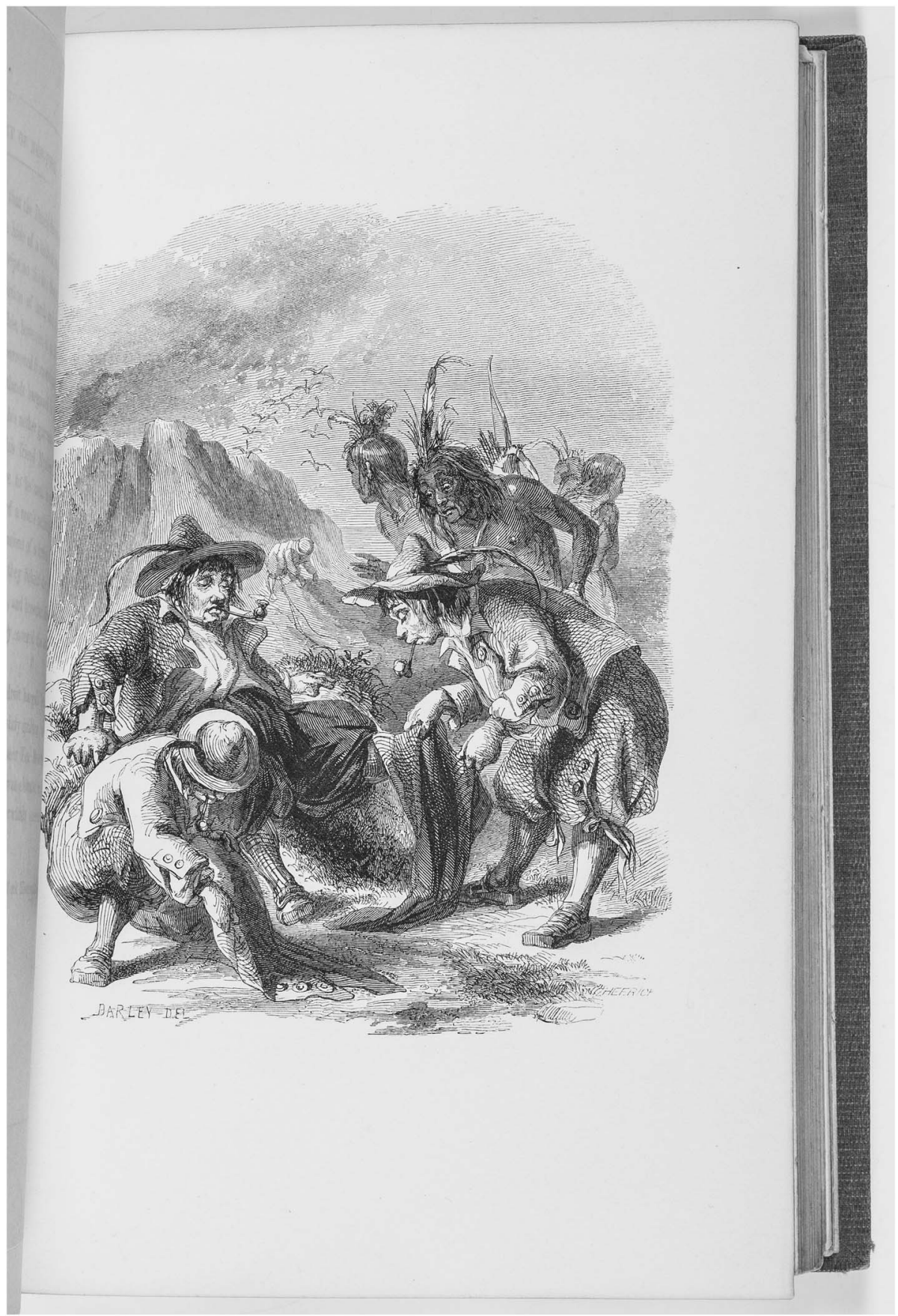

Figure 2. Mynheer Tenbroeck. Illustration by Felix O. C. Darley in Washington Irving's A History of New York (New York: George P. Putnam, 1850). Courtesy of The American Antiquarian Society. 
in strips no thicker than a child's finger, so as to take in a large portion of land, and to take in the Indians into the bargain. This, however, is an old fable which the worthy Dominie may have borrowed from antiquity. The true version is, that Oloffe Van Kortlandt bargained for just so much land as a man could cover with his nether garments. The terms being concluded, he produced his friend Mynheer Tenbroeck, as the man whose breeches were to be used in measurement. The simple savages, whose ideas of a man's nether garments had never expanded beyond the dimensions of a breech clout, stared with astonishment and dismay as they beheld this bulbousbottomed burgher peeled like an onion, breeches after breeches spread forth over the land until they covered the actual site of this venerable city.

This is the true history of the adroit bargain by which the island of Manhattan was bought for sixty guilders; and in corroboration of it I will add, that Mynheer Ten Breeches, for his services on this memorable occasion, was elevated to the office of land measurer; which he ever afterwards exercised in the colony.

*MSS of the Rev. John Heckwelder; New-York Historical Society. [Irving's note]

\section{The Cape of Good Hope, South Africa}

An oral tradition concerning the first Dutch settlement at the Cape of Good Hope, in 1652, was recorded nearly two centuries after the event by a French missionary, Thomas Arbousset.

\section{Thomas Arbousset, Narrative of An Exploratory Tour to the North-East of the Colony of the Cape of Good Hope, 1846 (original 1842) (53 $^{53}$}

Hanto was, in every respect, the most interesting Koranna we have known. He was of great stature, and well proportioned. He had fine black eyebrows, lively eyes, of a fine oval. He was endowed with a quick apprehension and retentive memory, and was considered well acquainted with the history of his tribe. To him we are indebted for the greater part of the information which follows.

"In the neighbourhood of the Cape of Good Hope, there lived, some eight generations back, a hottentot chief called KORA, whose name originated the name of the tribe. It was with him that the Europeans who first settled there, entered into treaty. According to an old tradition, they besought KORA to grant them as much land as they could surround with an ox-hide, cut into thongs. This appeared to KORA a very moderate request, and he granted it with the greatest readiness. But soon the strangers began to encroach upon the lands of the natives, and war was the consequence. KORA was then alive. It is not known whether, or no, he was slain in battle; but it is known that he died young. He left, as his successor, a son called ЕІкомо. He also had to defend his territory against the daily encroachments of the colonists. He could not long resist them, and he was ultimately driven back to the river Braak. Going from that place further to the north, he arrived amongst a numerous tribe of Hottentots wandering on the banks of the Gariep, and called Baroas (the hottentot bushmen.) He entered into treaty with them, and settled in that country, not far from the place where Griqua Town now stands. In that country lived and died Kuekib, Kongap, Kuenonkeip, Makabuté, and Kaup, the successors of Eiкомо.”

On comparing these traditions with the history of the Cape colony, we find some interesting coincidences. It was in 1652, that is about eight generations back, that vAN RIEBECK founded the colony. In 1659, vAN RIEBECK having made a distribution of lands amongst the dutch colonists, the Hottentots and they were involved in war. In 1669, peace was concluded with the aborigines, and the dutch were permitted to occupy a piece 
of land, stretching three miles along the shore. And in 1673, they were again at war with the Hottentots. But let us return to the Korannas.

\section{Bibliography}

\section{Unpublished Primary Sources}

Heckewelder, John. Letter to Samuel Miller, February 26, 1801. Miller Papers 1 (BV). New-York Historical Society.

\section{Primary Sources}

Alam, Muzaffar, and Sanjay Subrahmanyam. "Letters from a Sinking Sultan." In Aquém E Além Da Taprobana: Estudos Luso-Orientais À Memória De Jean Aubin E Denys Lombard, edited by Luis Filipe F. R. Thomas, 239-69. Lisbon: Universidade Nova de Lisboa, 2002.

Al-Makki Al-Asafi, Abudullah Muhammad. Zafar Ul Walih Bi Muzaffar Wa Alihi: An Arabic History of Gujarat. Translated by M. F. Lokhandwala. 2 vols. Baroda: Oriental Institute, 1970. Arbousset, Thomas. Narrative of an Exploratory Tour to the North-East of the Colony of the Cape of Good Hope. Translated by John Croumbie Brown. Cape Town, 1846.

Barbeau, Charles Marius. Huron and Wyandot Mythology: Geological Survey Memoir 80. Anthropological Series 11. Ottawa: Government Printing Bureau, 1915.

Bastian, Adolf. A Journey in Cambodia and Cochin-China (1864). Bangkok: White Lotus Press, 2005.

Carné, Louis de. Voyage en Indo-Chine et dans l'empire chinois. Paris, 1872.

The Epic of Hang Tuah. Translated by Muhammad Haji Salleh. Edited by Rosemary Robson-McKillop. Kuala Lumpur: Institut Terjemahan Negara Malaysia, 2010.

Furnivall, J. S., ed. "History of Syriam." The Journal of the Burma Research Society 5:1-3 (1915): 1-12, 49-57, 129-51.

Hamilton, Alexander. A New Account of the East Indies. London, 1744.

Hazard, Samuel, ed. Pennsylvania Archives. Vol. 1. First Series. Philadelphia, 1852.

Heckewelder, John Gottlieb Ernestus. History, Manners, and Customs of the Indian Nations Who Once Inhabited Pennsylvania and the Neighboring States. Philadelphia, 1881.

Irving, Washington. A History of New York: From the Beginning of the World to the End of the Dutch Dynasty. New York, 1850.

Kirimatiyawe. "The Maha Hatana Account, Late Seventeenth Century." In Portuguese Encounters with Sri Lanka and the Maldives: Translated Texts from the Age of Discoveries, edited and translated by Chandra Richard De Silva, 21-22. Surrey, England: Ashgate, 2009.

Livy. The Romane Historie Written by T. Livius of Padua Also, The Breviaries of L. Florus: Vvith a Chronology to the Vvhole Historie; and the Topography of Rome in Old Time. Translated out of Latine into English, by Philemon Holland, Doctor in Physick. To Which Is Now Added, A Supplement of the Second Decad of Livy (Which Was Lost.) Lately Written in Latine by I. Freinshemius, and Now Newly Translated into English. Early English Books Online. London, 1659.

Mailla, Joseph Anna-Marie de Moyria de. "Lettre du P. de Mailla." In Lettres edifiantes et curieuses: ecrite des missions etrangères, 14:1-85. Paris, 1720.

Morga, Antonio de. Sucesos De Las Islas Filipinas. Edited by José Rizal and W. E. Retana. Crónicas Y Memorias. Madrid: Ediciones Polifemo, 1997.

Raffles, T. S. The History of Java. Vol. 2. London, 1817. 
Rementer, J. email, February 25, 2007.

Sikandar. Mirati Sikandari; Or, The Mirror of Sikandar. Translated by Fazlullah Lutfallah Faridi. Bombay, 1899.

Swann, Brian. Algonquian Spirit: Contemporary Translations of the Algonquian Literatures of North America. Lincoln: University of Nebraska Press, 2005.

Virgil. The Works of Virgil Containing His Pastorals, Georgics and Aeneis: Adorn'd with a Hundred Sculptures / Translated into English Verse by Mr. Dryden. London, 1697. http:// quod.lib.umich.edu/cgi/t/text/text-idx?c=eebo;idno=A65112.0001.001

Zhang, Xie. Dong Xi Yang Kao. Bei jing: Zhong hua shu ju, 2000.

\section{Secondary Sources}

Axtell, James. After Columbus: Essays in the Ethnohistory of Colonial North America. Oxford: Oxford University Press, 1988.

Banner, Stuart. How the Indians Lost Their Land: Law and Power on the Frontier. Cambridge: Harvard University Press, 2005.

Biedermann, Zoltán. The "Portuguese Period" Revisited: New Perspectives on Sri Lanka in the Sixteenth Century. Colombo: International Centre for Ethnic Studies, n.d.

Burke, Peter. "A Survey of the Popularity of Ancient Historians, 1450-1700." History and Theory 5:2 (1966): 135-52.

Culhane, Peter. "Philemon Holland's Livy: Peritexts and Contexts." Translation and Literature 13:2 (2004): 268-86.

Davidson, James W. The Island of Formosa, Past and Present: History, People, Resources, and Commercial Prospects (1903). Oxford: Oxford University Press, 1988.

Silva, K. M. de. A History of Sri Lanka. London: C. Hurst, 1981.

Delâge, Denys. "La tradition orale de l'arrivée des Européens à New York." In Culture et Colonisation en Amérique du Nord: Canada, États-Unis, Mexique, edited by J. Lintvelt, R. Ouellet, and H. Hermans, 203-14. Quebec: Les Éditions du Septentrion, 1994.

Frazer, James G. "Hide-Measured Lands." The Classical Review 2:10 (December 1888): 322.

Hildebrandt, Stefan, and Anthony Tromba. The Parsimonious Universe: Shape and Form in the Natural World. New York: Copernicus, 1996.

Jackson, Jason Baird. "The Story of Colonialism, or Rethinking the Ox-Hide Purchase in Native North America and Beyond." Journal of American Folklore 126:499 (2013): 31-54.

—. Yuchi Ceremonial Life: Performance, Meaning, and Tradition in a Contemporary American Indian Community. Lincoln: University of Nebraska Press, 2003.

Jacobs, Jaap. Dutch Colonial Fortifications in North America 1614-1676. Amsterdam: The New Holland Foundation \& Bommelstein Historical Consultancy, 2015.

Kaiser, Siegrun. "Munsee Social Networking and Political Encounters with the Moravian Church." In Ethnographies and Exchanges: Native Americans, Moravians, and Catholics in Early North America, edited by A. G. Roeber, 145-64. University Park: Pennsylvania State University Press, 2008.

Laufer, Berthold. "The Relations of the Chinese to the Philippine Islands." Smithsonian Miscellaneous Collections 50:2 (1907): 248-84.

Lemire, Charles. Exposé chronologique des relations du Cambodge avec le Siam, L'Annam \& la France. Paris: Challamel Ainé, 1879.

Lupher, Donald A. Romans in a New World: Classical Models in Sixteenth-Century Spanish America. Ann Arbor: University of Michigan Press, 2003.

MacCormack, Sabine. On the Wings of Time: Rome, the Incas, Spain, and Peru. Princeton: Princeton University Press, 2007. 
Miles, Richard. Carthage Must Be Destroyed: The Rise and Fall of an Ancient Civilization. New York: Penguin Books, 2012.

Montgomery, Alexandra. "On Records: Delaware Indians, Colonists, and the Media of History and Memory." H-Net Reviews in the Humanities \& Social Sciences, December 2015, $1-2$.

Newman, Andrew. On Records: Delaware Indians, Colonists, and the Media of History and Memory. Lincoln: University of Nebraska Press, 2012.

Petković, Miodrag S. Famous Puzzles of Great Mathematicians. Providence: American Mathematical Society, 2009.

Reid, Anthony. "Early Southeast Asian Categorizations of Europeans." In Implicit Understanding: Observing, Reporting, and Reflecting on the Encounters Between Europeans and Other Peoples in the Early Modern Era, edited by Stuart B Schwartz, 268-94. Cambridge: Cambridge University Press, 1994.

Richter, Daniel K. Trade, Land, Power: The Struggle for Eastern North America. University of Pennsylvania Press, 2013.

Seed, Patricia. Ceremonies of Possession in Europe's Conquest of the New World 1492-1640. New York: Cambridge University Press, 1995.

Shepherd, John Robert. Statecraft and Political Economy on the Taiwan Frontier, 1600-1800. Stanford University Press, 1993.

Subrahmanyam, Sanjay. "On the Hat-Wearers, Their Toilet Practices, and Other Curious Usages." In Europe Observed: Multiple Gazes in Early Modern Encounters, edited by Kumkum Chatterjee and Clement Hawes, 45-81. Lewisburg: Bucknell University Press, 2008.

Thompson, Stith. Motif-Index of Folk-Literature; a Classification of Narrative Elements in Folktales, Ballads, Myths, Fables, Mediaeval Romances, Exempla, Fabliaux, Jest-Books, and Local Legends. 6 vols. Revised and enlarged edition. Bloomington: Indiana University Press, 1955.

Vansina, Jan. Oral Tradition as History. Madison: University of Wisconsin Press, 1985.

Waswo, Richard. The Founding Legend of Western Civilization: From Virgil to Vietnam. Hanover: Wesleyan University Press, 1997.

\section{Notes}

* Andrew Newman is Associate Professor of English and History at Stony Brook University. He's the author of On Records: Delaware Indians, Colonists, and the Media of History and Memory, and is completing a second book on representations of literacy practices in colonial American narratives of captivity among Native Americans.

1 Rementer, email.

2 Swann, Algonquian Spirit, 55-61.

3 Hazard, Pennsylvania Archives, 541.

4 Newman, On Records: Delaware Indians, Colonists, and the Media of History and Memory, 21, 154-61.

5 Petković, Famous Puzzles of Great Mathematicians, 96-98; see also Hildebrandt and Tromba, The Parsimonious Universe, 64-71.

6 Newman, On Records: Delaware Indians, Colonists, and the Media of History and Memory, 133-84.

7 Heckewelder to Miller, February 26, 1801.

8 Heckewelder, History, Manners, and Customs of the Indian Nations Who Once Inhabited Pennsylvania and the Neighboring States, $75 \mathrm{n} 1$.

9 Richter, Trade, Land, Power, 159; see also Delâge, "La Tradition Orale de L'Arrivée Des Européens À New York," 209; Axtell, After Columbus, 138; Banner, How the Indians Lost Their Land, 67; Jackson, "The Story of Colonialism, or Rethinking the Ox-Hide 
Purchase in Native North America and Beyond."

10 Thompson, Motif-Index of FolkLiterature, 251.

11 Frazer, "Hide-Measured Lands," 322.

12 Laufer, "The Relations of the Chinese to the Philippine Islands," 283-84.

13 Ibid., 282.

14 Davidson, The Island of Formosa, Past and Present, 12-13.

15 Reid, "Early Southeast Asian Categorizations of Europeans," 290-91.

16 Furnivall, "History of Syriam," 53.

17 Jackson, "The Story of Colonialism, or Rethinking the Ox-Hide Purchase in Native North America and Beyond," 40.

18 Ibid., 36.

19 On the "narrative account" as a genre of oral tradition, see Vansina, Oral Tradition as History, 82-83.

20 Barbeau, Huron and Wyandot Mythology, 269.

21 Jackson, Yuchi Ceremonial Life: Performance, Meaning, and Tradition in a Contemporary American Indian Community, 22-23.

22 Vansina, Oral Tradition as History, 15255; Seed, Ceremonies of Possession.

23 According to Patricia Seed, "Dutch mariners initially borrowed all their means to overseas empire from the Portuguese," including "their construction of fortified trading posts," and "many Dutch sailors and pilots on India-bound ships learned their craft on Portuguese vessels." Seed, Ceremonies of Possession, 149-50.

24 Miles, Carthage Must Be Destroyed, 73.

25 See MacCormack, On the Wings of Time; Waswo, Founding Legend; Lupher, Romans in a New World.

26 Seed, Ceremonies of Possession.

27 Montgomery, "On Records."

28 Virgil, The Works of Virgil Containing His Pastorals, Georgics and Aeneis, 216.

29 Burke, "A Survey of the Popularity of Ancient Historians, 1450-1700," 147. Books 11-20 of the Roman History were lost, but their contents were represented by epitomes or periochae that were composed in the fourth century. Culhane, "Philemon Holland's Livy: Peritexts and Contexts," 269-70.

30 Livy, The Romane Historie Written by T. Livius of Padua Also, The Breviaries of L. Florus.

31 Biedermann, The "Portuguese Period" Revisited, 16; De Silva, A History of Sri Lanka, 100.

32 Kirimatiyawe, "The Maha Hatana Account, Late Seventeenth Century," 21-22. Courtesy of Chandra Richard De Silva.

33 In the introduction to The Epic of Hang Tuah (2010), Rosemary RobsonMcKillip speculates that the stories that compose the text "had been flying around for many decades before and after the fall of Melaka, but were later collated." The Epic of Hang Tuah, xxi-xxii, xxv.

34 Ibid., 527-28. Courtesy of the Malaysian Institute of Translation \& Books.

35 Hamilton, A New Account of the East Indies, 137.

36 For discussion, see Subrahmanyam, brahmanyam, n, see East Indies decades before and after the fall of Melaka, 50-51, $78 \mathrm{n} 10$. For the written correspondence negotiating the cession at Diu, see Alam and Subrahmanyam, "Letters from a Sinking Sultan."

37 Al-Makki Al-Asafi, Zafar Ul Walih Bi Muzaffar Wa Alihi: An Arabic History of Gujarat, 215.

38 Sikandar, Mirati Sikandari; Or, The Mirror of Sikandar, 199.

39 It's also possible that there were independent oral traditions attributing the ruse to both the Portuguese and the Dutch. However, while de Carné does not specify a location, Charles Lemire, who closely paraphrases his account, identifies the same locale as Bastian ("Pnhéalu"), but attributes the ruse to Portuguese missionaries in 1553. Exposé Chronologique Des Relations Du Cambodge Avec Le Siam, L'Annam \& La France, 8.

40 Carné, Voyage en Indo-Chine et dans l'empire chinois, 12. My translation. 
41 Bastian, A Journey in Cambodia and Cochin-China (1864), 149.

42 Laufer, "The Relations of the Chinese to the Philippine Islands," 259; Morga, Sucesos De Las Islas Filipinas, 27.

43 Zhang xie, Dong Xi Yang Kao, 89. My thanks to Dr. Geoff Wade for locating this passage and providing the translation.

44 Raffles, The History of Java, 153-54.

45 Shepherd, Statecraft and Political Economy on the Taiwan Frontier, 1600-1800, 51, $460 \mathrm{n} 16$.

46 Mailla, "Lettre du P. de Mailla," 60-64. My translation.

47 Heckewelder, History, Manners, and Customs of the Indian Nations Who Once Inhabited Pennsylvania and the Neighboring States, 83.
48 See Kaiser, "Ethnographies and Exchanges," 145.

49 The first fort in the harbour may have been constructed not on the southern tip of Manhattan, but on Nooten (Governors) Island. Jacobs, Dutch Colonial Fortifications in North America 16141676, 6.

50 Heckewelder to Miller, February 26, 1801, 6 .

51 Heckewelder, History, Manners, and Customs of the Indian Nations Who Once Inhabited Pennsylvania and the Neighboring States, 77.

52 Irving, A History of New York, 121-22.

53 Arbousset, Narrative of an Exploratory Tour to the North-East of the Colony of the Cape of Good Hope, 24-26. 